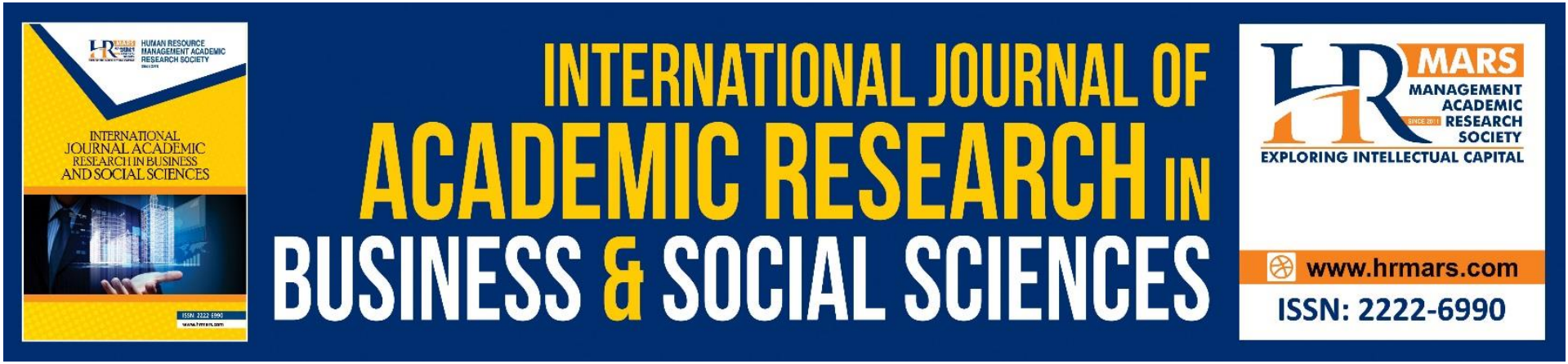

\title{
Systematic Literature Review: Mapping George Town as a UNESCO Creative City
}

Dina Miza Suhaimi

To Link this Article: http://dx.doi.org/10.6007/IJARBSS/v11-i4/9697

DOI:10.6007/IJARBSS/v11-i4/9697

Received: 02 February 2021, Revised: 05 March 2021, Accepted: 26 March 2021

Published Online: 16 April 2021

In-Text Citation: (Suhaimi, 2021)

To Cite this Article: Suhaimi, D. M. (2021). Systematic Literature Review: Mapping George Town as a UNESCO Creative City. International Journal of Academic Research in Business and Social Sciences, 11(4), 517-533.

Copyright: @ 2021 The Author(s)

Published by Human Resource Management Academic Research Society (www.hrmars.com)

This article is published under the Creative Commons Attribution (CC BY 4.0) license. Anyone may reproduce, distribute, translate and create derivative works of this article (for both commercial and non-commercial purposes), subject to full attribution to the original publication and authors. The full terms of this license may be seen

at: http://creativecommons.org/licences/by/4.0/legalcode

Vol. 11, No. 4, 2021, Pg. $517-533$

Full Terms \& Conditions of access and use can be found at http://hrmars.com/index.php/pages/detail/publication-ethics 


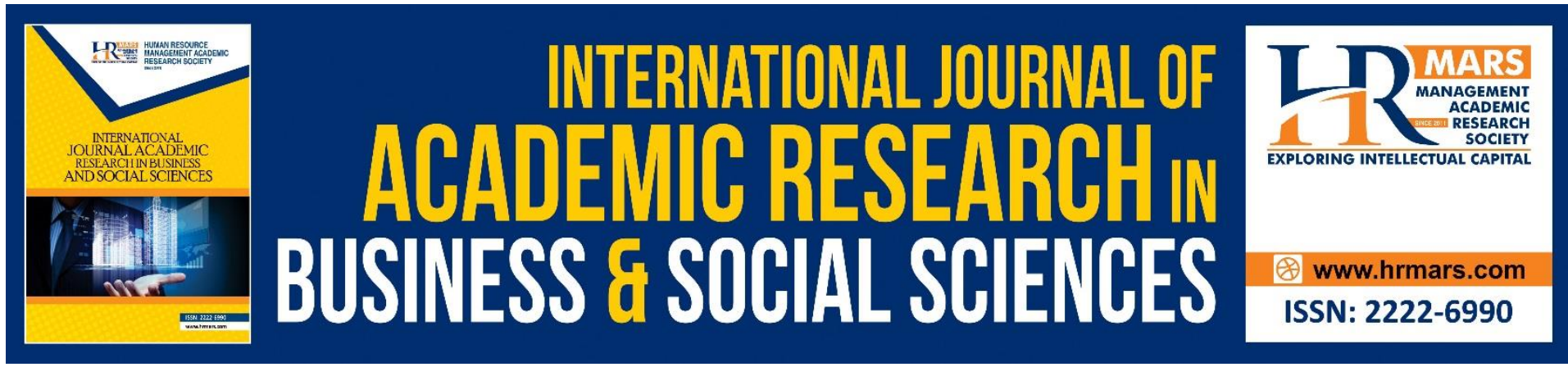

\title{
Systematic Literature Review: Mapping George Town as a UNESCO Creative City
}

\author{
Dina Miza Suhaimi \\ Faculty of Technical and Vocational, Universiti Pendidikan Sultan Idris Malaysia \\ Email: dinamiza2002@gmail.com
}

\begin{abstract}
UNESCO Creative Cities Network (hereafter UCCN) was established in 2004. The purpose of UCCN establishment is generally to facilitate the spread of cultural groups around the world; that include to exchange technical knowledge, experience, successful examples and to stimulate local economy and social development with the help of creative industries. UCCN covers seven creative categories that include crafts and folk art, creative fields, design, film, gastronomy, literature, media arts as well as music. UNESCO George Town Cultural World Heritage Site, Penang, Malaysia (hereafter UNESCO George Town) was successfully listed as a UNESCO Cultural World Heritage Site in 2008. Undoubtedly, the prestigious inscription has elevated UNESCO George Town's status and popularity, both domestically and internationally. Unfortunately, although the concept of UCCN is gaining credence from other region and countries, there is still a dearth of research in Malaysia on the nascent topic of UCCN. Thus, this paper aims to fill this research gap. The objectives of this paper are two-fold: (1) To critically analysing the potentials of UNESCO George Town, if at all, to be part of UNESCO Creative Cities Network (UCCN); and (2) To develop knowledge of systematic literature review (SLR) searching process with special reference to UNESCO George Town and UNESCO Creative Cities Network (UCCN). The findings of this paper revealed that there is a potential of UNESCO George Town to be branded as City of Gastronomy. The findings from this paper will perhaps benefit the key stakeholders and further elevate the status of UNESCO George Town, Penang, Malaysia.
\end{abstract}

Keywords: City of Gastronomy, UNESCO Creative Cities Network (UCCN), George Town, Penang, UNESCO.

\section{Introduction: UNESCO Creative Cities Network}

The United Nations Educational, Scientific and Cultural Organization (UNESCO) was established in the year 1945, in order to create peace through international cooperation in culture, sciences as well as education (Pearson, and Pearson, 2017). In 1972, the organization established the World Heritage List that identified sites with highly cultural and natural significance (Rosi, 2014). For inclusion on the prestigious list, sites must meet one or more of ten criteria of UNESCO's outstanding universal value (OUV) criteria. 
OUV can be described as natural and/or cultural superlative that are highly exceptional to transcend national boundaries and to be of common prominence for current and future generations. Fundamentally, the protections of these cultural and natural heritage properties are of the utmost importance to the community as a whole (Londen, et al., 2019). To date, UNESCO has listed 1,121 cultural, natural and mixed properties (sites) under five regions that consist of 167 state parties (countries) (UNESCO, 2020).

The selections of Cultural World Heritage Sites are based on six criteria: (i) human creative genius; (ii) interchange of human values; (iii) exceptional testimony to cultural tradition; (iv) significance stages in human history; (v) example of traditional human settlement; and (vi) heritage associated with events of outstanding universal significance. In addition, the selections of Natural World Heritage Sites are based on four remaining criteria of OUV: (vii) excellent natural phenomena or natural aesthetic importance; (viii) major stages of earth's history; (ix) significant on-going biological and ecological processes; and/or ( $x$ ) important natural habitats for conservation of biological diversity (UNESCO, 2020).

Apart from the remarkable establishment of Natural and Cultural World Heritage List, UNESCO introduced the UNESCO Creative Cities Network (UCCN) in late 2004 (Pearson, and Pearson, 2017). The UCCN now counts a total of 251 creative cities from 72 countries that are located in five regions (Minty and Nkula-Wenz, 2019). The aim of UCCN is to develop and promote inter-city members cooperation that placing creative criteria as a core factor of the cities' urban development plans as well as to ensure that the cities are safe, inclusive, resilient and sustainable (Biondi, et al., 2020; Podolskaya et al., 2020). Furthermore, the Network aims to stimulate local economy and social development, share experience and exchange knowledge with the assistance of creative industries (Stasiulis, 2017). There are seven recognised creative criteria that underpin the city members involvement in the UCCN; that can be chosen based on their preferences, namely design, music, crafts and folk art, literature, gastronomy, film and media arts (Alamoudy, 2013; Rodríguez-Gutiérrez, et al., 2020).

For cities to be granted as Cities of Crafts and Folk Art, they need to possess any of the following creative criteria: (i) on-going tradition of crafts or folk art; (ii) crafts and folk-art production; (iii) presence of craft artisans; (iv) crafts and folk-art related training centers; (v) promote crafts and folk art; and/or (vi) infrastructure that are relevant to crafts and folk art (UNESCO, 2020). A selection of Cities of Crafts and Folk-Art examples are Ouagadougou (Africa), Tunis (Arab States), Bamiyan (Asia and the Pacific), Paducah (Europe and North America) and Nassau (Latin America and the Caribbean).

In order to be registered as Cities of Music, the cities must meet any of these particular creative criteria: (i) being recognized as musical activities and centres; (ii) experience in hosting musical events at national and/or international level; (iii) promote the music industry; (iv) be the centres of music based institutions; ( $v$ ) informal structures for music education; (vi) platforms dedicated to music including from other countries; and/or (vii) cultural spaces that fit for listening and practicing music (Baker, 2017). A selected number of Cities of Music examples include Kinshasa (Africa), Ramallah (Arab States), Auckland (Asia and the Pacific), Liverpool (Europe and North America) and Salvador (Latin America and the Caribbean). 
Cities that aim to be listed as Cities of Design should oblige with any of these creative criteria: (i) reputable design industry; (ii) cultural landscape driven by design and the built environment; (iii) research centres and design schools; (iv) continuously practising designers at a local and/or national level; ( $v$ ) experience in hosting design related events; (vi) advantage for local designers and planners to take advantage of urban/natural conditions and local materials; and/or (vii) driven by design related creative industries (Stocker, 2019 ; UNESCO, 2020). A number of examples of Cities of Design consist of Cape Town (Africa), Dubai (Arab States), Nagoya (Asia and the Pacific), Berlin (Europe and North America) and Mexico City (Latin America and the Caribbean).

Cities with the intention to be entitled as Cities of Literature, the cities have to hold to any of these creative criteria: (i) the diversity, quantity and quality of publishing houses and editorial initiatives; (ii) quantity and quality of literature related programs in schools and tertiary institutions; (iii) environment where literature, poetry and/or drama draw an important role; (iv) experience in hosting events that promote both local and international literature; (v) bookstores, libraries and cultural centres committed to promote, preserve and disseminate the literature; (vi) active effort in translating literary works of local languages and foreign literature; and/or (vii) involved medias in strengthening the market for literary products and promoting literature (João, 2016 ). For instance, cities that represent the literature criteria comprise Durban (Africa), Beirut (Arab States), Lahore (Asia and the Pacific), Milan (Europe and North America) and Montevideo (Latin America and the Caribbean).

The criteria for cities to be accepted as Cities of Gastronomy include: (i) well-developed gastronomy that is characteristic of the urban centre and/or region; (ii) numerous gastronomy community that include chefs and/or traditional restaurants; (ii) traditional cooking with authentic ingredients; (iv) local know-how, traditional cooking methods that have survived technological/industrial advancement; (v) traditional food markets and industry; (vi) experience of hosting gastronomic related events; (vii) respect for the environment and sustainability of local products; and/or (viii) inclusion of biodiversity conservation programs in cooking schools curricula, promotion of nutrition in educational institutions and nurturing of public appreciation (Leng and Badarulzaman, 2014 ; Pearson and Pearson, 2017). Selected examples of Cities of Gastronomy are Overstand (Africa), Zahle (Arab States), Chengdu (Asia and the Pacific), Tucson (Europe and North America) and Panama City (Latin America and the Caribbean).

The criteria for cities to be renowned as Cities of Film include (i) important infrastructure related to cinema; (ii) links to the films related commercialization, production and distribution; (iii) experience in hosting events that are related to films; (iv) local and international collaborative initiatives; (v) film archives, institutes and/or private collections; (vi) film training centres and schools; (vii) disseminate films that are directed and/or produced locally or nationally; and/or (viii) encourage foreign films knowledge-sharing (UNESCO, 2020). Selections of designated Cities of Film examples are Wellington (Asia and the Pacific), Sofia (Europe and North America) and Santos (Latin America and the Caribbean).

The creative criteria for Cities of Media Arts consist of (i) develop creative and cultural industries triggered by digital technology; (ii) integrate media arts that leads to the improvement of urban life; (iii) progress of electronic art forms in quest of the involvement 
of civil society; (iv) culture accessibility via digital technology advancement; and/or (v) platforms for media artists (UNESCO, 2020). Miscellanies examples of Cities of Media Arts are Dakar (Africa), Sapporo (Asia and the Pacific), Austin (Europe and North America) and Santiago de Cali (Latin America and the Caribbean).

Overall, as of March 2020, there are a total of 251 UNESCO creative city members where 49 of them represent the Creative Cities of Crafts and Folk Art, followed by Creative Cities of Music (49), Creative Cities of Design (43), Creative Cities of Literature (39), Creative Cities of Gastronomy (36), Creative Cities of Film (18) and Creative Cities of Media Arts (17) (UNESCO, 2020) (see Figure 1).

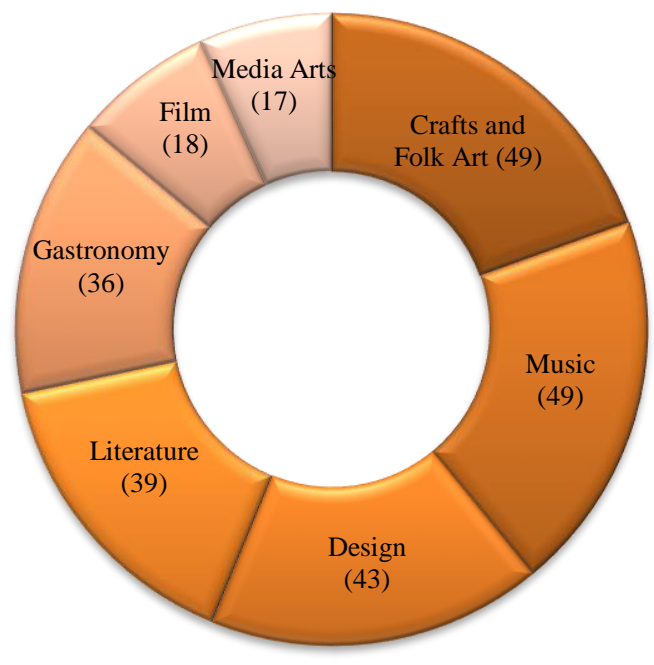

Figure 1. Number of UNESCO Creative City members within seven creative categories

\section{UNESCO George Town Cultural World Heritage Site, Penang, Malaysia}

George Town is the capital city of Penang, Malaysia (see Figure 2). In July 2008, UNESCO George Town was successfully listed as a Cultural World Heritage Site by UNESCO (Connolly, 2017). The inscription of UNESCO George Town was in accordance to UNESCO's Cultural OUV criteria that include criteria (ii), criteria (iii) and criteria (iv). Criteria (ii): demonstrate an interchange of human values and multi-cultural trading town in South and East Asia over a long span of time. Criteria (iii): demonstrate an exceptional living testimony of multi-cultural tangible and intangible heritage of Asia and colonial influences. Criteria (iv): demonstrate a mixture of influences of shophouses and townhouses without parallel anywhere in East and South Asia (Ramli, 2017). 


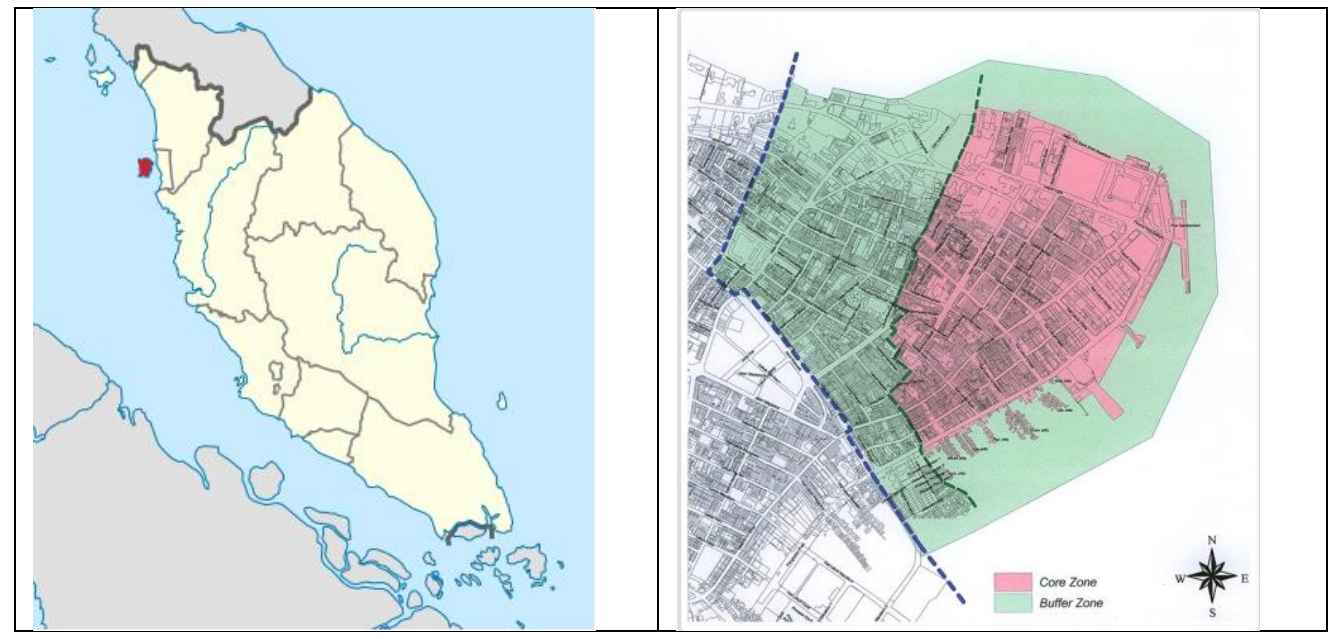

Figure 2. Penang and George Town.

Undoubtedly, the prestigious inscription has elevated George Town's status and popularity, globally. Penang is considered as second most visited destinations in Malaysia, after Kuala Lumpur (Mola, et al., 2011). Evidently, since the listing as a UNESCO status, the state's tourism industry has been showing a tremendous growth (Penang Monthly, 2015). In year 2007, a total of 5.19 million tourist arrivals to Penang were recorded (see Figure 3). Subsequently, year 2008 recorded a number of 6.31 million tourist arrivals to Penang. The following year recorded 5.96 million tourist arrivals to Penang, followed by 5.99 million (2010), 6.02 million (2011), 6.09 million (2012), 4.70 million (2013), 6.03 million (2014), 6.25 million (2015) and 6.60 million in 2016 (Omar et al., 2017).

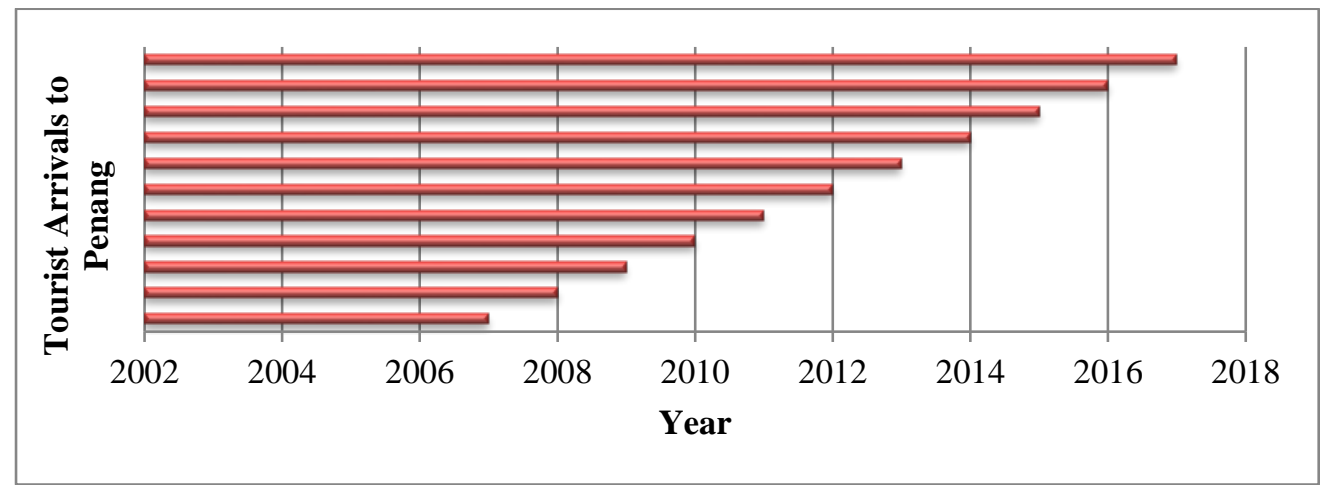

Figure 3. Tourist arrivals to Penang (2007 - 2016).

In addition, UNESCO George Town and Penang have received many national and international accolades, such as 10 Greatest Street Food Cities in Asia in 2012; World's 15 Best Street Art in 2013; World's 10 Best City to Visit in 2014 (Chang, Khoo and Badarulzaman, 2015); 15 Best Cities in the World for food by The Culture Trip; No. 1 in the 10 Best Budget Travel Destination by Forbes; Top 10 Best places in the world to retire by Conde Nast Traveller; 16 Must Visit Destinations by Los Angeles Times; No. 6 Best Places to Retire Abroad by CNN; No. 4 Best 10 Cities to Visit by Lonely Planet; No. 4 in the Top 10 cities list for Best in Travel by Lonely Planet (The Star, 2015); 20 Destinations with the Most Beautiful Beaches (You Can Actually Afford to 
Go To) in 2019 by The Travel; 12 best countries to retire in 2019 by New York Post (News Straits Times 2019 ); to name just a few.

Unfortunately, since the inscription in 2008, UNESCO George Town has not been listed to any seven of UNESCO'S creative city criteria. Moreover, with reference to UCCN, although the concept of UCCN is gaining credence from other region and countries, there is still a dearth of research of creative cities research in Malaysia (Khoo and Badarulzaman, 2014). Thus, this paper aims to fill this research gap. Therefore, this paper seeks to investigate the evidence of UNESCO George Town that is most likely entitled to be listed as a UNESCO Creative City. The following two-fold research objectives were addressed:

(1) The first objective is to critically analyze the potentials of UNESCO George Town, if at all, to be listed as a Creative City of Gastronomy.

(2) The second objective is to conduct the systematic literature review (SLR) searching process with special reference to UNESCO George Town and UNESCO Creative Cities Network (UCCN).

\section{Systematic Literature Review}

Systematic Literature Review (SLR) is among the most reliable methods of research (Torraco, 2005). SLRs are relevantly applicable in exploring new trends within disciplines (Pickering \& Byrne, 2014). This method allows boundaries to be mapped on what is already known, and consequently identifies gaps on what is yet to be known (Pickering et al., 2015). Unlike conventional literature review, SLRs are less rigid (Yang, et al., 2017; Snyder, 2019). An SLR can be perceived as a stand-alone research that clearly delineates a field and provides answers to quite specific questions (Warren and Becken, 2017). A SLR has to be valid, repeatable, systematic in the approach, comprehensive in scope and explicit in procedure (Fink, 2005; Pickering and Byrne, 2014; Xiao and Watson, 2019).

The documentation of SLR process has been identified as one of the vital parts of a successful review (Brocke et al. 2009). The quantity and quality of literature derived from SLR is critically dependent on the processes of 'garbage-in' and 'garbage-out' or inclusion and exclude. Therefore, the quantity of articles to be included in SLRs is usually not more than 50 and often less than 10 (Robinson and Lowe, 2015). Moreover, this method can minimise bias on literature review as it provides highly systematic procedures (Shaffril et al.; 2019).

The SLR protocol and standard of publications are frequently applies in the field of medical researches (Tranfield, et al., 2003; Durach et al., 2017), however, the SLR-based researches have increased across other research fields (Schryen 2015), such as in the field of social sciences by Petticrew and Roberst (2006), software engineering field (Kitchenham and Charters, 2007), information systems area (Okoli and Schabram, 2010), supply chain management (Durach et al., 2017), education (Xiao and Watson, 2019), entrepreneurship (Kraus et al., 2020) as well as hospitality and tourism (Thees, et al., 2020). Given all the advantages of SLR, this paper opted for a SLR method. The SLR process for this paper was performed in March 2020. 


\section{Research Methodology: SLR}

This particular section explains a thorough step-by-step process of SLR that includes database resources, inclusion and exclusion or 'garbage-in' and 'garbage-out' criteria, systematic review process and data abstraction and analysis which are employed in this paper.

\section{Database Sources}

Online databases offer a considerable collection of published literature (Petticrew and Roberts, 2006). No single database gathers the complete set of published documents; therefore, a SLR search should draw from a few databases where two databases are exceptional (Xiao and Watson, 2019). This paper retrieved a number of articles via Scopus and Google Scholar databases.

\section{Scopus Searching Functions}

Scopus allows multiple functions that include keywords, synonyms, phrase searching, truncation, Boolean operators, search string and field code.

\section{Keywords}

The keywords for SLR searching process should be derived from the research questions. The research questions can be grouped into concept keywords (Kitchenham and Charters 2007). For instance, this paper's research question is "which creative field does UNESCO George Town best entitled to?" Based on the research question, the keywords for this paper can be 'unesco creative city' and 'unesco george town penang.'

\section{Synonyms}

The keywords can be extended by synonyms (Rowley and Slack 2004). For example, the synonym words of 'unesco creative city' can be 'unesco creative town'. The synonym words of 'unesco george town' can be 'george town heritage site', 'george town penang', 'georgetown', and the like.

\section{Phrase Searching}

The phrase searching in Scopus uses "double quotes" or inverted commas around the phrase. These functions allow Scopus to search for more than two words and join the words together, so the words will be searched as a phrase (King's College London, 2020). Selected examples of phrase searching used in this paper are "unesco creative city" and "unesco george town penang". Doing so, Scopus will search for materials where "unesco creative city" and "unesco george town penang" are used as a phrase.

\section{Truncation}

Truncation functions as variations identification of keywords. The truncation is indicated with an asterisk or star symbol $(*)$ at the end of the keywords (Bettany-Saltikov, 2012). In this paper, truncation is applied for the word 'city' $\rightarrow$ 'cit*. The word 'cit* can be searched as 'city' and 'cities'.

\section{Boolean Operator 'OR'}

It is an advantage for the researchers to know how to establish search strings using Boolean operators (Fink 2005). The function of Boolean operator 'OR' is to include one or more synonyms of the keywords. The Boolean operator 'OR' must be included in between the 
synonym words. Effectively, the synonym words using Boolean operator 'OR' should be in the same bracket. A selection of examples of synonym words using Boolean operator 'OR' for this paper can be ("unesco creative citi* network" OR "unesco creative cit*" OR "creative cit*").

\section{Boolean Operator 'AND'}

The function of Boolean operator 'AND' is to join the domains (Breretona et al. 2007). Effectively, the joined of the domains using Boolean operator 'AND' must include double bracket at the beginning and end of the search string. The search using Boolean operator 'AND' for this paper can be (("unesco creative cit* network" OR "unesco creative cit*" OR "creative cit*") AND ("george town" OR "george town penang" OR georgetown OR "pulau pinang" OR penang)).

\section{Field Code}

There is a selection of field code functions available in Scopus database namely 'ALL', 'TITLE', 'TITLE-ABS', 'TITLE-ABS-KEY', 'TITLE-ABS-KEY-AUTH', and the like. In this paper, the researchers will only use the 'TITLE-ABS-KEY' field code function where the keywords are widely retrieved.

\section{Search string}

A search string is an arrangement of words and phrases. The search string for this paper is TITLE-ABS KEY (("unesco creative cities network" OR "unesco creative cit*" OR "creative cit*") AND ("george town" OR "george town penang" OR georgetown OR "pulau pinang" OR penang OR malaysia)) (see Figure 4).

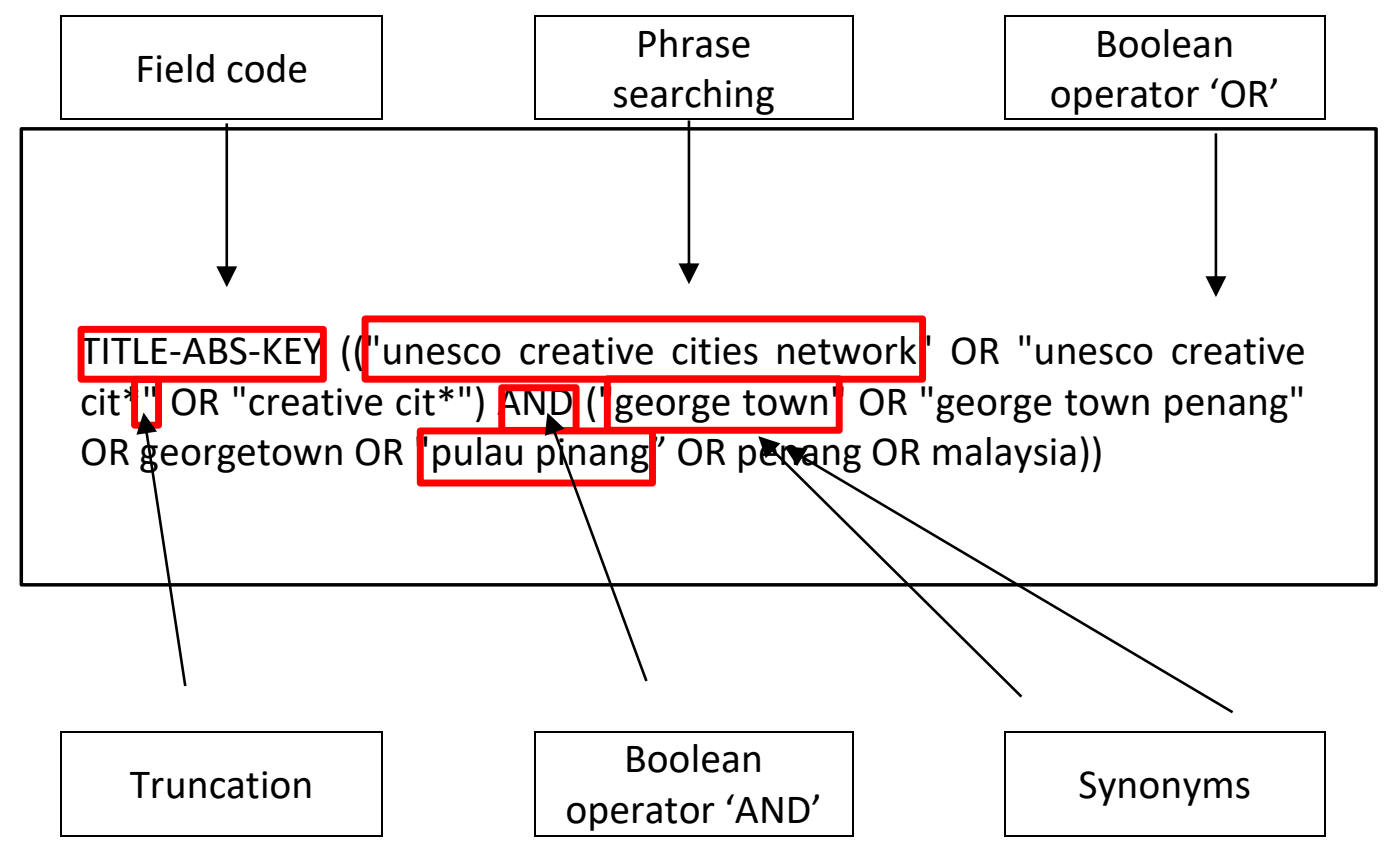

Figure 4. Scopus advanced search string 


\section{Google Scholar searching functions}

Google Scholar database has a limited search functions (De Winter et al., 2014). It allows the functions of synonyms, phrase searching, Boolean operator 'OR', Boolean operator 'AND', field code and search string. There is a slight difference for Google Scholar's Boolean operator 'AND', field code and search string searching functions.

\section{Boolean operator 'AND'}

The Boolean operator 'AND' in Google Scholar is best replaced by bracket. For an example, instead of (city) AND (george town), use (city)(george town).

\section{Field code}

There are two field code functions in Google Scholar, namely (i) 'in the title of the article' and (ii) 'anywhere in the article'. The first field code function allows the database to search for the keywords written mainly in the title of the articles; the latter field code allows the database to search for the keywords in the title, keywords and/or abstract of the articles.

\section{Search string}

Google Scholar's search string for this paper is: allintitle: ("unesco creative cities network" OR "unesco creative city" OR "unesco creative cities" OR "creative city" OR "creative cities")("george town" OR "george town penang" OR georgetown OR "pulau pinang" OR penang) (see Figure 5).

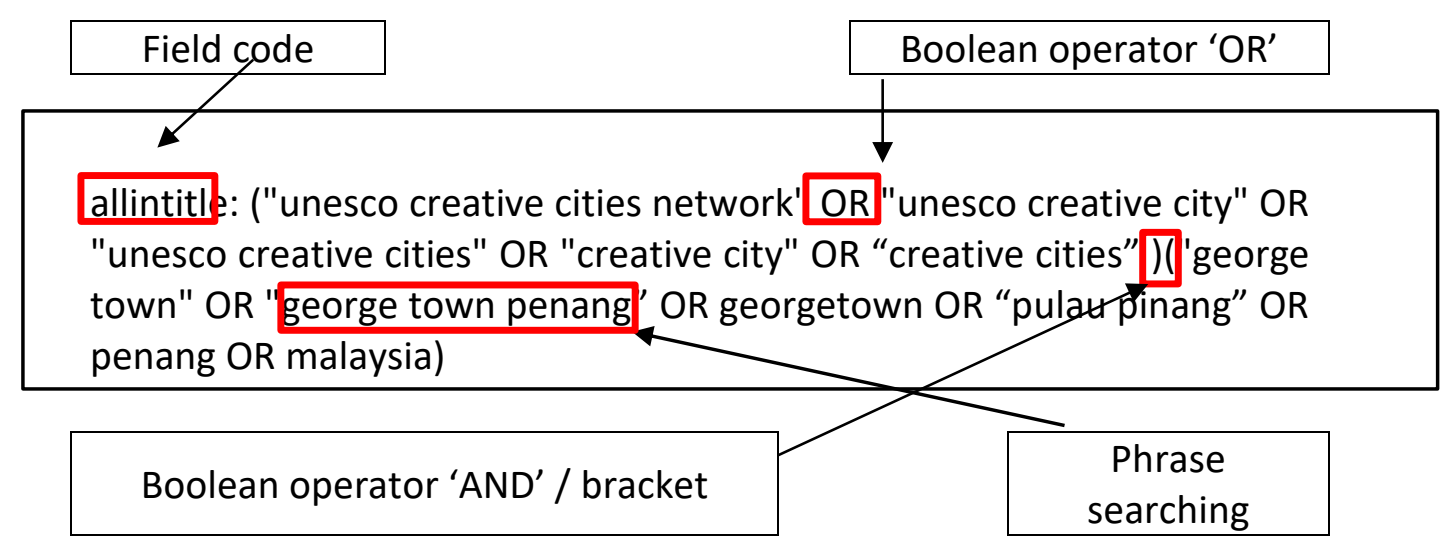

Figure 5. Google Scholar advanced search string details

\section{The SLR Process}

The SLR process in selecting articles consists of 'identification', 'screening' and 'eligibility' phase (Gough, et al., 2017 and Shaffril et al.; 2019).

\section{Phase 1: Identification}

According to Fink (2005), the process of SLR searching involves identifying the keywords, searching for synonyms of the words and followed by establishing the search string. For this paper, seven articles were retrieved through Scopus database (refer Table 1) and 23 articles were retrieved through Google Scholar database (see Table 1). 
Table 1. Scopus advanced search string

\begin{tabular}{|l|l|}
\hline Scopus & $\begin{array}{l}\text { TITLE-ABS-KEY (("unesco creative cities network" OR "unesco creative } \\
\text { cit*" OR "creative cit*") AND NOT ("george town" OR "george town } \\
\text { penang" OR georgetown OR "pulau pinang" OR penang OR melaka OR } \\
\text { malaysia)) }\end{array}$ \\
\hline
\end{tabular}

Based on the Google Scholar advanced searching, 23 articles were retrieved in the identification phase of SLR process (see Table 2).

Table 2. Google Scholar advanced search string

\begin{tabular}{|l|l|}
\hline Google Scholar & $\begin{array}{l}\text { allintitle: ("unesco creative cities network" OR "unesco creative city" } \\
\text { OR "unesco creative cities" OR "creative city" OR "creative } \\
\text { cities")("george town" OR "george town penang" OR Georgetown OR } \\
\text { "pulau pinang" OR penang OR Malaysia) }\end{array}$ \\
\hline
\end{tabular}

\section{Phase 2: Screening}

The second phase was to screen that 30 articles based on the 'garbage-in' and 'garbage-out' or inclusion and exclusion criteria. The only criterions were the exclusion of subject area: environmental science. In total, two articles were omitted based on the exclusion criteria. Google Scholar screened and returned articles between 2008 and 2020. A total of 13 articles were omitted.

\section{Phase 3: Eligibility}

The third phase is eligibility, where only two articles retrieved from Scopus database were relevant to this paper that mainly focus on George Town as a Creative City based on UCCN. As for Google Scholar, one redundant article that is retrieved from Google Scholar database was omitted.

\section{Inclusion}

As a final point, the remaining articles included and ready to be analyzed for this paper resulted in a total of three articles (see Figure 6). 

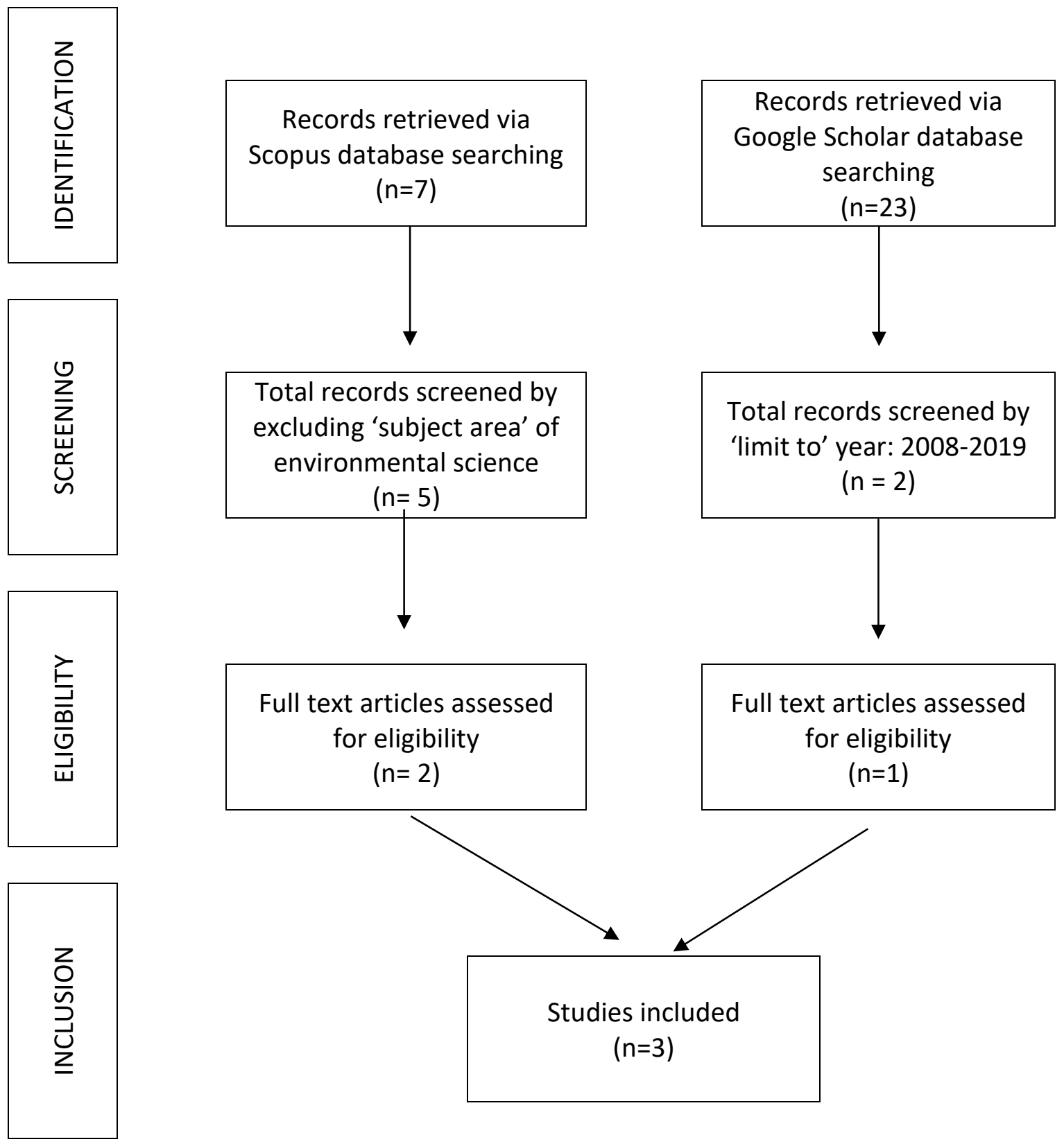

Figure 6. SLR flowchart of George Town as a UCCN

Findings and Discussions

Based on the SLR processes, there are only three eligible articles included and ready to be analyzed in this paper (see Table 3). 
Table 3. Findings

\begin{tabular}{|c|c|c|c|}
\hline Vo & Authors/Years & Objective & Findings \\
\hline 1 & $\begin{array}{l}\text { Khoo and } \\
\text { Badarulzaman, } \\
2014 \text { (a) }\end{array}$ & $\begin{array}{l}\text { To discuss the prevalent trends of } \\
\text { exploiting cultural capital such as } \\
\text { gastronomic legacy to ignite } \\
\text { redevelopment of contemporary } \\
\text { cities as illustrated in the city of } \\
\text { George Town, Penang, Malaysia. }\end{array}$ & $\begin{array}{l}\text { This paper proposes that George } \\
\text { Town should leverage on its } \\
\text { various gastronomic legacies as a } \\
\text { strategic asset to formally listed } \\
\text { among other Creative Cities of } \\
\text { Gastronomy. }\end{array}$ \\
\hline 2 & $\begin{array}{l}\text { Khoo and } \\
\text { Badarulzaman, } \\
2014 \text { (b) }\end{array}$ & $\begin{array}{l}\text { To explore the role of Nasi Kandar } \\
\text { in contributing George Town, } \\
\text { Penang as a UNESCO Creative City } \\
\text { of Gastronomy. }\end{array}$ & $\begin{array}{l}\text { The findings provide empirical } \\
\text { evidence that urban gastronomy } \\
\text { in George Town does shape and } \\
\text { motivate local and foreign tourists } \\
\text { alike to pay a visit to the city. This } \\
\text { is a valid construct to position } \\
\text { George Town as a City of } \\
\text { Gastronomy. }\end{array}$ \\
\hline 3 & $\begin{array}{l}\text { Khoo and } \\
\text { Badarulzaman, } \\
2014 \text { (c) }\end{array}$ & $\begin{array}{l}\text { To explore the viability of branding } \\
\text { George Town, Penang as a } \\
\text { UNESCO Creative City of } \\
\text { Gastronomy. }\end{array}$ & $\begin{array}{l}\text { The findings revealed that George } \\
\text { Town qualifies to be branded as } \\
\text { City of Gastronomy. }\end{array}$ \\
\hline
\end{tabular}

In general, the findings showed that all the three articles were written by the same authors and in the same year (2014). However, the objectives of the studies differ from one another. The objective of the first article: 'Branding George Town World Heritage Site as City of Gastronomy: Prospects of Creative Cities Strategy in Penang' (Khoo \& Badarulzaman, 2014 (a)) is to analyze the gastronomic heritage as demonstrated in the heritage city of George Town. The findings suggest that, in line with UCCN flagship, the city of UNESCO George Town should place the city's gastronomic heritage as a strategic advantage to formally listed along other Creative Cities of Gastronomy. The objective of the second article: 'Factors Determining George Town as a City of Gastronomy' (Khoo \& Badarulzaman, 2014 (b)) is to explore the role of Nasi Kandar in contributing George Town, Penang as a UNESCO Creative City of Gastronomy. The findings provide empirical evidence that urban gastronomy in George Town does shape and motivate local and foreign tourists alike to visit the city. This is a reasonably valid construct to position George Town as a City of Gastronomy. The objective of the third article is to explore the viability of branding George Town, Penang as a UNESCO Creative City of Gastronomy. The findings revealed that George Town qualifies to be branded as a UNESCO Creative City of Gastronomy.

This paper attempted to systematically analyze the existing literature on the potentials of George Town to be branded as a UNESCO Creative City. A rigorous reviewed sourced from Scopus and Google Scholar databases have resulted in 3 relevant articles. There are seven creative criteria of UCCN; namely crafts and folk art, music, design, literature, gastronomy, film and media arts (Alamoudy, 2013; Rodríguez-Gutiérrez, et al., 2020). The findings of this paper strongly indicate that George Town is eligible to be branded as a City of Gastronomy. 


\section{Limitations and Future Research}

Firstly, this paper only involved three articles. This shows that there is still a dearth of research about UCCN in Malaysia (Khoo \& Badarulzaman, 2014). Although the quantity of articles to be included in SLR researches can be less than ten (Robinson and Lowe, 2015), the researchers strongly suggest that more quantity of researches on UCCN in Malaysia should be gathered so that George Town could properly positioned and branded as a creative city based on its outstanding preferences.

Secondly, this paper only focused Nasi Kandar that originally belongs to the Indian Muslim community. Whereas, as a UNESCO Heritage Site, George Town comprised multi-ethnic community such as Malay, Indonesian descendants, Arabs, Chinese, Straits Chinese, Indian, just to name a few. These multi-ethnic communities have their own particular food to represent their ethnic groups. Hence, future research should investigate the factors determining other ethnic groups' food vis-à-vis the branding of UNESCO George Town as a City of Gastronomy under UCCN.

Thirdly, this paper is mainly focusing on UNESCO George Town. However, UNESCO Cultural World Heritage Site in 2008 was jointly inscribed with Melaka. Therefore, in future, similar research should be focused on Melaka, so that both UNESCO cultural heritage sites can be analysed and best branded based on the sites' creative criteria.

Fourthly, this paper applied SLR method that was based on two databases, namely Scopus and Google Scholar. In addition, the number of articles included in this paper is a bit too small. Although SLR focuses on quality instead of quantity of the articles, and there is no minimum number of SLR articles is required; as for future research, the researchers suggest that more databases should be used so that the quantity of quality articles can be increased.

\section{Conclusion}

As a conclusion, this paper contributes to the knowledge of SLR searching process that is specifically focusing on tourism field with special reference to UNESCO George Town as a UNESCO Creative Cities Network.

\section{Corresponding Author}

Dina Miza Suhaimi (Ph.D.)

Faculty of Technical and Vocational, Universiti Pendidikan Sultan Idris, 35900, Tanjong Malim, Perak, Malaysia.

Email: dinamiza2002@gmail.com

\section{References}

Abdullah, J., Azam, R., and Bustami, R. (2013). Socio-economic and Cultural Sustainability of Muslims in Georgetown World Heritage Site. Procedia-Social and Behavioural Sciences, 85, 217-226.

Atikahambar, Y., Zainal, A., Rahayu, M., and Mokhtar, R. (2018). Quality of Food and Tourists' Satisfaction of Penang Delicacies in Predicting Tourists' Revisit Intention. International Journal of Academic Research in Business and Social Sciences, 8(12), 1606-1618.

Bettany-Saltikov, J. (2012). How to Do a Systematic Literature Review in Nursing: A Step-ByStep Guide. McGraw-Hill Education (UK). 
Burnham, J. F. (2006). Scopus database: a review. Biomedical digital libraries, 3(1), 1.

Cheng, K. G. (2017). The Cheapskate Highbrow and the Dilemma of Sustaining Penang Hawker Food. SOJOURN: Journal of Social Issues in Southeast Asia, 32(1), 36-77.

Connolly, C. (2017). Whose landscape, whose heritage? Landscape politics of 'swiftlet farming' in a World Heritage City. Landscape Research, 42(3), 307-320.

Durach, C. F., Kembro, J., and Wieland, A. (2017). A new paradigm for systematic literature reviews in supply chain management. Journal of Supply Chain Management, 53(4), 6785.

Farahani, B. M., Abooali, G., \& Mohamed, B. (2012). George Town World Heritage Site: What We Have and What We Sell?. Asian Culture and History, 4(2), 81.

Fink, A. (2005). Conducting Research Literature Reviews: From the Internet to Paper, $2^{\text {nd }}$ ed. Thousand Oaks, CA: Sage.

Foo, R., and Krishnapillai, G. (2019). Preserving the intangible living heritage in the George Town World Heritage Site, Malaysia. Journal of Heritage Tourism, 14(4), 358-370.

Gani, A. A., Mahdzar, M., Mohamad, R., Abdullah, N., Shahril, Z., and Awang, K. W. (2017). Linking Image and Satisfaction of Food Tourism in Penang, Malaysia. E-Proceeding of the $6^{\text {th }}$ International Conference on Social Sciences Research 2017 (ICSSR 2017). Kuala Lumpur, Malaysia.

Genc, R. (2017). Gastronomic Heritage in Tourism Management. Asia-Pacific Journal of Innovation in Hospitality and Tourism, 6(1), 1-14.

Hun-Kean Cheah, H., Goh, Y., Isa, S. M., Mohaidin, Z. (2018). Customers' Behavioural Intentions towards Heritage Café in the George Town World Heritage Site (WHS), Penang, Malaysia. Journal of Business and Social Development, 6(1), 109-119

Khoo, S. L., and Badarulzaman, N. (2014) Factors Determining George Town as a City of Gastronomy. Tourism Planning and Development, 11(4), 371-386.

Kivela, J., and Crotts, J. C. (2006). Gastronomy tourism: A meaningful travel market segment. Journal of Culinary Science and Technology, 4(2), 39-55.

Latiff, K., Ng, S. I., Aziz, Y. A., \& Basha, N. K. (2019). Food authenticity as one of the stimuli to world heritage sites. British Food Journal.

Leng, K. S., \& Badarulzaman, N. (2014). Branding George Town world heritage site as city of gastronomy: prospects of creative cities strategy in Penang. International Journal of Culture, Tourism and Hospitality Research.

Leong, Q., Karim, M. S. A., Awang, K. W. and Bakar, A. Z. A. (2017). Profiles of Gastronomic Tourists Visiting Malacca and George Town, World Heritage Site(s) of Malaysia. AsiaPacific Journal of Innovation in Hospitality and Tourism. Vol. 6 No. 1 p. 99-120

Leong, Q. L., Ab Karim, S., Awang, K. W., \& Bakar, A. Z. A. (2017). An integrated structural model of gastronomy tourists' behaviour. International Journal of Culture, Tourism and Hospitality Research.

Marzuki, A. (2010). Tourism development in Malaysia. A review on federal government policies. Theoretical and Empirical Researches in Urban Management, (17), 85.

Mohamed, B., Omar, S. I., and Abidin, S. Z. Z. (2015). The Perils of Tourism Growth in a World Heritage Site: The Case of George Town, Penang.

Moher, D., Liberati, A., Tetzlaff, J., Altman, D. G. (2009). Preferred reporting items for systematic reviews and MetaAnalyses: the PRISMA statement. PLoS Med. 6 (7)

Musa, M., and Feng, K. L. (2016). Initiating an Oral History Project in a Multicultural UNESCO World Heritage Site of George Town, Penang, Malaysia: Challenges and Outcomes. Kajian Malaysia: Journal of Malaysian Studies, 34(2). 
Omar, S. I., Abukhalifeh, A. A. N., and Mohamed, B. (2015). An Importance-Performance Analysis of International Visitors to Penang Island, Malaysia. Tourismos: An International Multidisciplinary Journal of Tourism, 10(1), 15-36.

Omar, S. I., Mohamad, D., Rozelee, S., and Mohamed, B. (2017). Holiday satisfaction in Penang, Malaysia: A quantitative perspective analysis of international and domestic tourists. Geografia: Malaysian Journal of Society and Space, 11(7).

Pazil, A. H. M., and Razak, R. C. (2019). Perspectives of Asian Employers on Graduates' Soft Skills: A Systematic Review. Universal Journal of Educational Research, 7(11), 23972405.

Petticrew, M., and Roberts, H. (2006). Systematic Reviews in the Social Sciences. A Practical Guide, Malden: Blackwell.

Ramli, Z. (2017). Heritage Tourism in Malaysia: Potential and Challenges. The Social Sciences, 12(3), 431-440.

Reid, A. (1993). Southeast Asia in the Early Modern Era: Trade, Power, and Belief. Cornell University Press.

Richard, B., and Richard, B. (2017). Hotel chains: survival strategies for a dynamic future. Journal of Tourism Futures, 3(1), 56-65.

Rowley, Jennifer, and Slack, F. (2004). Conducting a Literature Review." Management Research News 27 (6): 31-39.

Sayed, R. (2017). Promoting Local Community Integration in World Heritage Site Planning: George Town, Penang, Malaysia

Shaffril, H. A. M., Samah, A. A., Samsuddin, S. F., and Ali, Z. (2019). Mirror-mirror on the wall, what climate change adaptation strategies are practiced by the Asian's fishermen of all? Journal of cleaner production.

Shahminan, R. N. R. (2008). Kajian Tipologi Rumah Kedai Awal Era Belanda Di Bandar Melaka: Sumbangan Kepada Bidang Pemuliharaan Di Malaysia. Ph.D. thesis, Universiti Sains Malaysia.

Torraco, R. J. (2005). Writing integrative literature reviews: Guidelines and examples. Human Resource Development Review, 4, 356.

Xiao, Y., and Watson, M. (2019). Guidance on conducting a systematic literature review. Journal of Planning Education and Research, 39(1), 93-112.

\section{Web Pages}

CNN Travel. (2017). Retrieved on 20 March 2020 from http://travel.cnn.com/penang/

CNNGo. (2011). Retrieved in March 2020 from https://www.travelfeeder.com/travel_guides/cnngo-50-most-delicious-foods-in-theworld-malaysian-assam-laksa-is-7th

GTWHI. (2012). Intangible Cultural Heritage in the Historic City of George Town: A Case study of the 20 practitioners. Retrieved in March 2020 from http://gtwhi.com.my/images/pdfs/Heritage\%20Traders\%20of\%20George\%20Town.pd $f$

King's College London. (2020). Retrieved in March 2020 from https://libguides.kcl.ac.uk/systematicreview/advanced

Penang Monthly. (2015). Retrieved in March 2020 from http://www.investpenang.gov.my/files/investmentupdates/31/Penang\%20Economic \%20Indicator\%20Q2\%202015.1432708522.pdf 
The Culture Trip. (2016). Retrieved in March 2020 from https://theculturetrip.com/northamerica/usa/articles/the-15-best-cities-in-the-world-for-food/

The Star. (2014). Retrieved on 20 March 2020 from https://www.thestar.com.my/news/nation/2014/02/04/lonely-planet-penang-foodtop-spot/

UNWTO. (2017). Retrieved on 20 March 2020 from http://people.unica.it/carlamassidda/files/2017/06/UNWTO_TourismHighlights_2017.pdf 